\title{
PELAKSANAAN BANK GARANSI SEBAGAI SUATU JAMINAN PROYEK PADA PEMBIAYAAN PROYEK PEMERINTAH DI PROVINSI RIAU
}

\author{
Yosi Mandagi \\ Universitas Riau, Indonesia, yosi_mandagi@yahoo.co.id
}

\begin{abstract}
Banking services and credit, in the form of a Bank Guarantee, one form of an individual guarantee institution, including a debt guarantee agreement. Issuance of Bank Guarantees, the bank takes over guaranteed obligations if the guaranteed collateral against the recipient of the guarantee. So a bank guarantee is a form of conditional engagement, the condition of which is a condition where the debtor is declared to have been negligent or defaulted. The issuance of a bank guarantee does not guarantee that the performance charged to the party is guaranteed, but the bank guarantee only guarantees or covers when the person is guaranteed to default. To overcome the risk of issuing a Bank Guarantee, the bank requests the guaranteed party to provide a "counter guarantee" which has a minimum cash value equal to the amount of money set as collateral and is listed in the bank guarantee.
\end{abstract}

Keywords: Bank Guarantee, Default

\begin{abstract}
Abstrak
Pelayanan jasa dan kredit perbankan, dalam bentuk Bank Garansi salah satu bentuk lembaga jaminan perorangan, termasuk perjanjian penanggungan hutang. Penerbitan Bank Garansi, pihak bank mengambil alih kewajiban terjamin bila si terjamin melakukan wanprestasi terhadap penerima jaminan. Jadi bank garansi merupakan bentuk perikatan bersyarat, yang syaratnya adalah suatu keadaan dimana si berutang dinyatakan telah lalai atau wanprestasi. Penerbitan bank garansi tidak menjamin akan terlaksananya prestasi yang dibebankan terhadap pihak terjamin, akan tetapi bank garansi hanya menjamin atau menanggung manakala si terjamin melakukan wanprestasi. Untuk mengatasi resiko atas pengeluaran Bank Garansi, bank meminta lebih dahulu kepada pihak yang dijamin untuk memberikan "jaminan lawan "(counter guarantee/kontra garansi) yang nilai tunainya sekurangkurangnya sama dengan jumlah uang yang ditetapkan sebagai jaminan dan tercantum di dalam bank garansi Kata Kunci: Bank Garansi, Wanprestasi.
\end{abstract}




\section{Latar Belakang}

Pelaksanaannya jaminan yang dipersyaratkan dalam proyek pemerintah adalah jaminan yang dikeluarkan oleh perbankan dalam bentuk bank garansi. Bank garansi diartikan sebagai pemberian janji secara tertulis dari bank kepada obligee untuk jangka waktu, jumlah dan keperluan tertentu bahwa bank akan membayar kewajiban principal apabila yang bersangkutan wanprestasi kepada obligee.

Bank garansi, sebagaimana sifatnya, adalah suatu penjaminan dari bank dimana diperlukan syarat-syarat dan kondisi tertentu agar supaya penjamin melaksanakan kewajibannya. Kondisi dimaksud adalah adanya suatu peristiwa "wanprestasi" atau "default" atau "tidak dipenuhinya kewajiban" oleh terjamin kepada pihak yang menerima jaminan. Prinsip inilah yang harus dipegang teguh dan dipahami oleh seluruh masyarakat tentang bank garansi. Atau dengan kata lain Bank garansi adalah jaminan yang diberikan oleh bank dengan tujuan memberikan jaminan kepada pihak penerima jaminan bahwa bank sebagai penjamin akan memenuhi segala kewajiban sebagaimana telah dijanjikan apabila pihak terjamin (nasabah) tidak memenuhi kewajibannya pihak terjamin dalam hal ini adalah pemborong atau kontraktor adalah perusahaanperusahaan yang bersifat perorangan yang berbadan hukum atau badan hukum yang bergerak dalam bidang pelaksanaan pemborongan. Pemborong bisa perorangan maupun badan hukum, baik pemeritah maupun swasta. Bagi proyek-proyek pemerintah pemborong harus berbadan hukum.

Dasar hukum yang dijadikan landasan dalam pelaksanaan bank garansi adalah KUH Perdata Buku Ketiga Bab XVII dari pasal 1820 sampai dengan pasal 1850 yakni perihal penjaminan dan Peraturan Bank Indonesia dalam bentuk Surat Keputusan Direksi Bank Indonesia No.23/88/KEP/DIR tanggal 18 Maret 1991 yang diedarkan melalui Surat Edaran No.23/7/UKU tanggal 18 Maret 1991 tentang Pemberian Bank Garansi oleh Bank. ( SEBI No. 23/7/UKU/1991 tanggal 18 Maret 1991) Bank garansi pihak yang mengajukan permohonan umumnya harus memberikan agunan senilai $100 \%$ dari nilai bank garansi yang dikeluarkan oleh pihak bank. Dampak diterbitkan produk penjaminan untuk pelaksanaan proyek, seperti bank garansi memberikan alternatif pilihan kepada pemilik proyek untuk menentukan akan menggunakan produk yang mana sebagai salah satu syarat dalam pemberian proyek. Disamping itu juga bagi pihak principal pun juga terbantu apabila principal tersebut kurang mempunyai modal yang cukup untuk memberikan agunan $100 \%$ dalam penerbitan bank garansi.

Bank garansi bagi bank yang mengeluarkannya mengandung risiko di waktu mendatang apabila terjamin ternyata cidera janji. Juga dapat 
dimengerti oleh karena hal ini maka bank akan berusaha untuk membatasi risiko yang mungkin timbul di waktu mendatang. Bank meminta kepada terjamin untuk memberikan jaminan lawan. Jaminan lawan dapat berupa uang tunai atau lainnya seperti giro, deposit, surat-surat berharga dan harta kekayaan lainnya apabila jaminan lawan berupa harta kekayaan lain maka jumlah nilainya harus sebesar $150 \%$ dari jumlah barang-barang yang dapat di asuransikan, harus di asuransikan yang disetujui oleh bank dan tercantum dalam polis asuransi. Premi asuransi menjadi tanggungan yang terjamin.

Bank garansi merupakan suatu bentuk dari perjanjian penangguhan hutang maka ketentuan dalam Pasal 1338 ayat 1 KUH Perdata tentang "kebebasan berkontrak"berlaku terhadap suatu perjanjian garansi dalam bentuk apapun." Ketentuan bahwa bank sebagai penanggung mensyaratkan adanya provisi dari debitur untuk peruntukan siapa ia mengikatkan diri sebagai borq serta sejumlah uang atau deposito yang disetorkan pada bank.(Asser Rutten: hlm. 222)

Bilamana dikemudian hari seorang nasabah wanprestasi, bank yang telah menyetujui memberikan jaminan mempunyai kewajiban untuk melakukan pembayaran kepada pihak penerima jaminan sejak saat dilaksanakannya pembangunan tersebut, maka hubungan antara pihak bank dengan nasabah berubah menjadi pihak kreditur yakni bank dan pihak debiturnya adalah nasabah. Hal itu berarti nasabah mempunyai kewajiban untuk melunasi hutangnya kepada bank sebesar nilai pertanggungan dalam bank garansi.

Dalam suatu garansi atau jaminan biasanya terdapat dua kontrak:
a. Principle Contract merupakan Kontrak yang memuat kewajiban suatu pihak tertentu, misalnya kewajiban mengenai penyerahan atau levering atau pembayaran.

b. Contract of Guaranty yaitu Adanya pihak yang menjamin kontrak yaitu bank.

Untuk mendapatkan bank garansi yang diinginkan sesuai dengan tujuan penggunaannya, seorang atau pengusaha atau instansi/lembaga yang mengajukan permohonan untuk mendapatkan bank garansi dari suatu bank, maka harus memenuhi beberapa syarat atau prosedur yang telah ditetapkan oleh bank yang bersangkutan dalam hal pemberian bank garansi. Sedangkan bagi bank yang mengeluarkan bank garansi merupakan suatu pernyataan tertulis atau janji tertulis yang isinya menyetujui untuk mengikatkan diri pada penerima jaminan guna memenuhi kewajiban terjamin dalam suatu jangka waktu tertentu dan dengan syarat-syarat tertentu berupa pembayaran sejumlah uang tertentu apabila terjamin dikemudian hari ternyata tidak memenuhi kewajibannya kepada penerima jaminan. Dengan adanya 
pemberian bank garansi diharapkan pihak penerima jaminan tidak perlu menyediakan dana cadangan untuk meneruskan pekerjaan atau perjanjian yang telah dibuatnya dengan pihak terjamin seandainya pihak terjamin tersebut nantinya wanprestasi, sehingga nantinya akan terdapat kepastian hukum bila para pihak yang terlibat ingin mewujudkan kegiatan tersebut. Contohnya dapat dilihat pada kasus No. 124/ PDT/G/2011/PN.PBR. dan Nomor 214/Pdt.G/2016/PN Pbr.

Kasus

No.

124/

PDT/G/2011/PN.PBR Pan United sebagai Penggugat melawan PT Riau Makmur Sentosa sebagai tergugat 1 dan PT. Surya Dumai Agrindo sebagai tergugat 2. Kasus Nomor 214/Pdt.G/2016/PN Pbr PT Mawatindo Road Contruction merupakan penggugat dan Kementerian Riset, Teknologi dan Pendidikan Tinggi cq Universitas Riau selaku tergugat. Pada tanggal 11 Agustus 2015 antara Penggugat dengan Tergugat telah menandatangani Surat Perjanjian untuk melaksanakan Paket Pekerjaan Konstruksi Pembangunan Konstruksi Gedung B Rumah Sakit Pendidikan UR Nomor: 526/UN 19/PPK/2015 dan Adendum Kontrak Nomor 1091/UN 19/PPK/2015 tanggal 10 Desember 2015.

Perumusan Masalah Berdasarkan uraian pada latar belakang di atas, maka dapat dirumuskan permasalahan sebagai berikut:Bagaimana pelaksanaan bank garansi sebagai suatu jaminan proyek pada pembiayaan proyek pemerintah di
Provinsi

Riau.Bagaimana tanggungjawab para pihak dalam pelaksanaan bank garansi sebagai suatu jaminan proyek dalam pembiayaan proyek pemerintah di Provinsi Riau jika terjadi wanprestasi. Bagaimana upaya hukum mengatasi wanprestasi dalam pelaksanaan bank garansi sebagai suatu jaminan proyek dalam pembiayaan proyek pemerintah di Provinsi Riau.

Tujuan Penelitian Untuk mengetahui pelaksanaan bank garansi sebagai suatu jaminan proyek pada pembiayaan proyek pemerintah di Provinsi Riau.Untuk mengetahui tanggungjawab para pihak dalam pelaksanaan bank garansi sebagai suatu jaminan proyek dalam pembiayaan proyek pemerintah di Provinsi Riau jika terjadi wanprestasi.Untuk mengetahui upaya hukum mengatasi wanprestasi dalam pelaksanaan bank garansi sebagai suatu jaminan proyek dalam pembiayaan proyek pemerintah di Provinsi Riau.

\section{Metode Penelitian}

Penelitian merupakan suatu sarana pokok dalam pengembangan ilmu pengetahuan. Hal ini disebabkan, oleh karena penelitian bertujuan untuk mengungkapkan kebenaran secara sistematis, metodologis dan konsisten. Melalui proses penelitian tersebut diadakan analisa dan konstruksi terhadap data yang telah dikumpulkan dan diolah. ( Soerjono Soekanto dan Sri Mamuji, 2011;1)

Menurut Bambang Sunggono, Penelitian pada dasarnya adalah merupakan suatu upaya pencarian dan 
bukannya sekedar mengamati dengan teliti sesuatu objek yang mudah terpegang oleh tangan ( Bambang Sunggono,2003;27). Penelitian ini dibuat dalam bentuk normatif, yaitu penelitian yang menitik beratkan kepada data sekunder berupa norma hukum tertulis. Hukum tertulis yang digunakan adalah Kitab Undang-Undang Hukum Perdata.Dilakukan dengan cara studi kepustakaan untuk mengumpulkan data primernya, dan menggunakan metode Deskriptif, karena penelitian ini bertujuan untuk mendikripsikan tidak terbatas hanya sampai pengumpulan dan penyusunan data, tetapi meliputi analisis dan interprestasi tentang arti data itu ( Handari Nawawi,2003; 23).

\section{Hasil dan Pembahasan}

\section{Pelaksanaan Bank Garansi Sebagai Suatu Jaminan Proyek Pada Pembiayaan Proyek Pemerintah di Provinsi Riau .}

Peran strategis bank salah satunya mampu menghimpun dan menyalurkan dana kepada masyarakat dalam bentuk kredit dan atau bentuk-bentuk lainnya dalam rangka meningkatkan taraf hidup rakyat banyak (Pasal 1 butir 2 UndangUndang Nomor 7 Tahun 1992 jo Undang- Undang Nomor 10 Tahun 1998 Tentang Perbankan). Salah satu jasa yang ditawarkan oleh pihak bank ialah bank garansi. Bank Garansi adalah jaminan tertulis bank kepada pihak penerima jaminan dimana bank mengikatkan diri untuk membayar sejumlah uang tertentu apabila pihak pemohon tidak memenuhi kewajibannya kepada pihak penerima jaminan berdasarkan kesepakatan/kontrak antara pihak pemohon dengan pihak penerima jaminan. ${ }^{1}$

Salah satu tugas bank dalam menerbitkan Bank Garansi, untuk kepentingan nasabahnya dengan tujuan memberikan bantuan yang sifatnya menunjang nasabah yang melakukan suatu pembelian tidak membutuhkan kredit bank. Bank Garansi diberikan untuk melaksanakan pembangunan proyek dengan perjanjian antara pemborong dan pemberi pekerjaan pembangunan proyek, untuk pembelian barang, dan untuk mendapatkan Keterangan Pemasukan Pabean (KPP) atas barang-barang yang Letter of Credit-nya (L/C belum dibayar penuh oleh importer (Thomas Suyatno, M. M., Djuhaepah T,2003;66).

Adapun jenis-jenis Bank Garansi yang ditawarkan oleh Bank adalah sebagai berikut:( Achmad Anwari ,1980; 29).

1. Bank Garansi Penawaran (Bid Tender Bond) adalah Suatu pengambilalihan kewajiban membayar oleh pihak penjamin (Guarantor) atas permintaan peserta tender (Principal) kepada pihak penyelenggara tender (Bouwheer) dimanapenjamin mengambil kewajiban untuk membayar kepada penyelenggara tender sampai

1 Disampaikan pada kegiatan Kerja Praktek: Bank Garansi, Jakarta Tanggal 9 Agustus 2010. 
sejumlah uang tertentu jika peserta tidakmemenuhi kewajibannya dalam pununjukan sebagai pemenang tender.

2. Bank Garansi Pelaksanaan (Performance Bond) adalah Suatu pengambilalihan kewajiban membayar oleh pihak penjamin (Guarantor) atas permintaan supplier/kontraktor (Pricipal) kepada pihak pembeli/pemberi kerja (Beneficiary) dimana penjamin mengambil alih kewajiban untuk membeyar kepada pihak pembeli/ pemberi kerja sampai sejumlah uang tertentu jika supplier/kontraktor tidak memenuhi kewajibannya dalam realisasi pekerjaan sesuai dengan yang telah diperjanjikan.

3. Bank Garansi untuk penerimaan uang muka kerja (Advance Payment Bond) adalah Suatu pengambilan kewajiban membayar oleh pihak penjamin atas permintaan kontraktor kepada pemilik proyek (Bouheer)untuk menjamin penerimaan pembayaran uang muka proyek yang diterima oleh kontraktor dari pemilik proyek.

4. Bank Garansi untuk Pemeliharaan (Retention Bond) adalah Suatu pengambilalihan kewajiban membayar oleh pihak penjamin atas permintaan kontraktor kepada pemilik proyek dalam rangka jaminan pemeliharaan terhadap proyek yang telah diselesaikan oleh kontraktor.

Mekanisme permohonan Bank Garansi pada bank ini adalah bahwa pemohon Bank Garansi harus memenuhi ketentuan-ketentuan sebagai berikut (Lia Laurensia,2007;2-3) :

a. Pemohon harus sudah memiliki rekening giro aktif pada Bank tersebut.

b. Mengajukan surat permohonan tertulis yang dilengkapi dengan :

i. Undangan lelang (untuk Bank Garansi Penawaran/Tender)

ii. SPK (Surat Perintah Kerja) / penunjukan (untuk Bank Garansi Pelaksanaan)

iii. Kontrak kerja (untuk Bank Garansi Uang Muka)

iv. Berita acara penyerahan (untuk Bank Garansi Pemeliharaan)

v. Jaminan lawan (kontra garansi) yang disediakan.

Setiap jaminan yang diberikan oleh bank selalu berpedoman pada ketentuan-ketentuan dan peraturanperaturan yang ditetapkan oleh pemerintah dan bank sentral serta pada kelaziman yang berlaku dikalangan perbankan. Oleh karena bank garansi mengandung suatu tingkat risiko tertentu, maka pertimbangan tentang risiko ini perlu dilakukan sehingga dalam pemberian bank garansi si terjamin dituntut untuk menyediakan jaminan lawan. (kontra garansi). Jadi dapat dikatakan bahwa setiap jaminan yang diberikan pada bank garansi adalah mutlak dan tidak bisa diganggu gugat agat tercipta keadialan yang mana bank wajib memberikan garansi dan penerima garansi wajib memenuhi persyaratannya agar tidak tumpang tindih di kemudian hari. 
Tersedianya kontra garansi ini dinyatakan dalam nilai tunai yang dianggap cukup oleh bank. Yaitu dapat berupa (M. Djumhana,1996;223) :

1. Uang tunai yang disetor kebank yang bersangkutan

2. Dana Giro yang dibekukan.

3. Deposito

4. Surat-surat berharga

5. Harta kekayaan berupa :

a. Barang bergerak

b. Barang tak bergerak

c. Harta tak berwujud seperti tagihan

d. Hal-hal lain yang sifatnya serupa dengan itu.

6. Harta kekayaan lain yang dapat diterima oleh bank yang bersangkutan.

Bank mewajibkan pemohon bank garansi untuk menyediakan jaminan lawan atas bank garansi yang diterbitkan, karena apabila terjadi wanprestasi maka secara administrasi perbankan bank garansi akan berubah pos menjadi kredit yang diberikan karena didalam ketentuan perkreditan jaminan agunan harus disediakan. Semua ini agar dapat menjamin terpenuhinya hak dan kewajiban serta kepastian hukum.

Adapun perbedaan antara bank garansi dengan kredit adalah bahwa bank garansi diberikan dalam bentuk sertifikat (bank garansi penawaran, bank garansi pelaksanaan, bank garansi uang muka, dan bank garansi pemeliharaan), sedangkan kredit diberikan langsung berupa dana baik secara tunai maupun dalam bentuk over booking.
Dalam menangani permohonan bank garansi, Bank di Riau melakukan penelitian dan pertimbanganpertimbangan terlebih dahulu yang pada hakekatnya sama dengan penelitian yang dilakukan dalam pemberian kredit, yaitu :

a. Mempertimbangkan aktivitas rekening giro si pemohon bank garansi.

b. Meneliti sejarah perusahaan dalam melaksankan proyek.

c. Mempertimbangkan karakter pemilik perusahaan

d. Meneliti kelengkapan syaratsyarat pengajuan bank garansi.

Bank Garansi untuk melakukan pekerjaan/proyek yang dibiayai oleh pemerintah yaitu (Ignatius Ridwan Widyadharma, 1995;64) :

a) Bank garansi penawaran, dengan nilai jaminan sebesar 1-3\% dari nilai proyek yang ditawar.

b) Bank garansi pelaksanaan, dengan nilai jaminan sebesar $5 \%$ dari nilai proyek/kontrak

c) Bank garansi uang muka, dengan nilai jaminan sebesar antara 20-30\% dari nilai proyek/kontrak untuk golongan ekonomi lemah dengan kualifikasi C-2 diberikan uang muka sebesar $30 \%$ dari nilai kontrak, sedangkan untuk golongan ekonomi menengah keatas dengan kualifikasi C-1, B dan A diberikan uang muka sebesar $20 \%$ dari nilai kontrak. 
d) Bank garansi pemeliharaan, dengan nilai jaminan sebesar $5 \%$ dari nilai kontrak.

Dengan catatan sebagai berikut :

1. Untuk nilai kontrak yang kurang dari Rp. 50.000.000 (lima puluh juta) adanya bank garansi

penawaran dan bank garansi

pelaksanaan tidak diperlukan.

2. Bagi pemborong yang tidak mengambil uang muka, maka bank garansi uang muka tidak diperlukan.

3. Bagi pemborong yang mengerjakan proyek dengan masa pemeliharaan melebihi batas akhir tahun anggaran maka agar sisa dana yang belum dicairkan sebesar 5\% tidak menjadi hangus maka pencairannya bisa diganti dengan bank garansi pemeliharaan dengan nilai jaminan minimal sama dengan nilai proyek yang ditagih.

4. Bagi pemborong yang mengerjakan proyek dengan masa pemeliharaannya tidak melampui batas akhir tahun anggaran maka bank garansi pemeliharaan tidak diperlukan.

Adapun mekanismenya adalah (Widjanarto, 1995;75-76.) :

a. Panitia lelang mengumumkan pendaftaran peserta lelang.

b. Perusahaan yang mendaftarkan diri sebagai peserta diseleksi oleh panitia lelang.

c. Bagi perusahaan yang lulus seleksi dikirimi surat undangan pengambilan dokumen lelang. d. Panitia lelang mengadakan anwijzing, yaitu pertemuan antara panitia lelang dengan peserta tender yang dimaksudkan untuk memberikan penjelasan mengenai dokumen lelang yang telah diberikan, meliputi pula penjelasan administrasi, maupun teknis mengenai pelaksanaan proyek dan juga melakukan peninjauan ke lokasi proyek.

e. Dua hari setelah Aanwijzing, panitia lelang menerbitkan berita acara Aanwijzing (yang berisi mengenai hasil dari penjelasan pada waktu Aanwijzing, penentuan nilai jaminan yaitu sebesar 1-3\% dari nilai proyek yang ditawar, dan masa berlaku jaminan penawaran) yang ditandatangani oleh panitia lelang dan 2 (dua) orang wakil dari perusahaan rekanan peserta tender. Berita acara Aanwijzing ini digunakan sebagai dasar atau pedoman pembuatan penawaran.

f. Sebagai syarat untuk membuat penawaran penyedia jasa mengajukan permohonan bank garansi kepada Bank dengan mekanisme sebagai berikut:

f.1. Mengajukan surat permohonan kepada bank dengan melampirkan :

f.1.1. Fotocopy undangan dari panitia lelang

f.1.2. Syarat-syarat tamabahan yang diminta oleh pihak bank berupa akta pendirian PT, TDR (Tanda Daftar 
Rekanan) NPWP (Nomor Induk Wajib Pajak), SIUJK (Surat Ijin Jasa Konstruksi), RAB (Rencana Anggaran Biaya), RAP (Rencana Anggaran Pelaksanaan) Neraca perusahaan terakhir, Daftar Susunan Pengurus dan personalia, Daftar Peralatan, KTP Direktur dan Pemilik Jaminan lawan.

f.2. Sebelum menyetujui permohonan bank garansi, pihak Bank melakukan serangkaian penelitian antara lain mempertimbangkan aktivitas rekening giro si pemohon bank garansi, meneliti sejarah perusahaan/pemborong dalam melaksanakan proyek mempertimbangkan

karakter pemilik perusahaan.

f.3. Setelah bank menyetujui pemberian bank garansi maka dibuat surat perjanjian bank garansi dihadapan notaris, kemudian diterbitkan surat bank garansi.

g. Bank garansi penawanan yang diterbitkan tersebut dilampirkan dalam penawaran yang dianjurkan.

h. Setelah peserta tender mengajukan penawaran maka dilakukan evaluasi, kemudian diadakan penentuan lelang. i. Pemenang lelang diumumkan melalui media massa, radio siaran pemerintah dan Assosiasi (KADIN, GAPENSi).

j. Terhadap pengumuman pemenang lelang itu disediakan masa sanggah selama 4 hari setelah pemgumuman lelang diterbitkan. Surat sanggah tersebut ditujukan kepada atasan langsung dari panitia lelang yaitu kepala Dinas Pekerjaan Umum Bina Marga.

k. Jika tidak ada sanggahan maka diterbitkan surat penunjukkan pemenang dan surat perintah kerja.

1. Sebagai pemenang tender maka dibuat surat kontak untuk melaksanakan proyek. Untuk itu diperlukan Bank garansi pelaksanaan. Prosedur pengajuan bank garansi pelaksanaan sama dengan pengajuan bank garansi penawaran ditambah dengan lampiran surat perintah kerja dari pemimpin proyek, sertifikat tanah sebagai jaminan lawan, menyetor uang tunai sebesar $10 \%$ dari nilai jaminan yang diminta sebagai cover dan uang tersebut baru bisa dicairkan kembali setelah masa jaminan berakhir (90hari).

Bank garansi dalam perjanjian pemborongan merupakan salah satu syarat yang diminta oleh pimpinan proyek atau pemberi pekerjaan terhadap para rekanan dengan maksud agar 
proyek yang dilaksanakan dapat berjalan lancar sehingga risiko-risiko yang mungkin terjadi akan ditanggung oleh pihak bank. Namun begitu dalam pelaksanaannya sebaiknya adan suatu lembaga independen yang dapat menilai pekerjaan seperti apa yang layak untuk mendapatkan bank garansi.

Surat perjanjian bank garansi mengatur tentang syarat-syarat terbitnya surat bank garansi yang harus disepakati, dimana surat perjanjian tersebut telah disediakan oleh pihak bank yang isinya sekurang-kurangnya memuat klausul-klausul sebagai berikut (Widjanarto, 1995;75-76.):

1. Tujuan penggunaan bank garansi

2. Jumlah / nilai tertinggi bank garansi

3. Tanggal mulai berlaku serta jangka waktu bank garansi

4. Tempat kedudukan / domisili terjamin dan bank.

5. Macam jaminan lawan (kontra garansi) yang diserahkan oleh terjamin kepada bank serta nilainya.

6. Terjamin tunduk kepada instruksiinstruksi dan peraturan-peraturan yang dikeluarkan oleh pemerintah dan bank sentral serta kelaziman yang berlaku dikalangan perbankan.

7. Biaya bank garansi yang harus dibayar oleh terjamin baik macamnya maupun jumlahnya seperti provisi dan biaya-biaya lain yang timbul sehubungan dengan pemberian bank garansi
8. Terjamin tunduk kepada ketentuan-ketentuan dan peraturan-peraturan tentang pemberian bank garansi yang ditetapkan oleh bank seperti ketentuan bahwa bank garansi dapat diubah atau dibatalkan secara sepihak, contohnya oleh pihak bank atau pihak yang dijamin.

9. Terjamin memberi kuasa yang tidak dapat dicabut kembali kepada bank sewaktu-waktu mencairkan jaminan lawan (kontra garansi) guna melunasi utang terjamin, baik sebagai akibat dilaksanakannya pembayaran bank garansi yang timbul sehubungan dengan pemberian bank garansi tersebut.

Tanggungjawab Para Pihak Dalam Pelaksanaan Bank Garansi Sebagai Suatu Jaminan Proyek Dalam Pembiayaan Proyek Pemerintah di Provinsi Riau Jika Terjadi Wanprestasi.

Apabila pemohon Bank Garansi melakukan kesalahan sehingga terjadi wanprestasi berakibat terjadinya klaim, maka (H.R. Daeng Naja,2005;34) :

a. Klaim bank garansi tersebut dianggap sah apabila diajukan oleh pemegang atau penerima bank garansi dengan menyerahkan asli warkat, bilyet atau sertifikat bank garansi dan tidak melebihi jangka waktu sesuai dengan klausula yang 
tercantum dalam warkat, bilyet atau sertifikat bank garansi.

b. Bank seyogianya menghubungi nasabah pemohon bank garansi untuk melakukan negosiasi dan menyelesaikan kewajibannya atas terjadinya klaim, apakah akan diselesaikan secara sekaligus lunas atau dengan pemberian fasilitas kredit.

Pengawasan yang dilakukan oleh bank pemberi garansi adalah secara kualifikatif dan kuantitaif dengan tujuan untuk memperoleh gambaran tentang keadaan keuangan dan harta kekayaan serta jalannya perusahaan terjamin. Pengawasan yang dilakukan oleh Bank terhadap pengawasan yang dilakukan pengguna bank garansi/terjamin adalah secara administrasi mencatat tanggal jatuh tempo bank garansi dan melakukan pengawasan terhadap rekening giro si terjamin. Langkah yang dilakukan oleh Bank jika bank garansi telah jatuh tempo adalah memindahkan secara administrasi dari bank garansi ke dalam rekening kreditur atau rekening penampungan.

Jika terjadi wanprestasi dalam perjanjian pemborongan maka pihak yang memborongkan (pemimpin proyek) maka terlebih dahulu memberi teguran agar pemborong (terjamin) memenuhi kewajibannya sebagaimana yang telah diperjanjikan dalam jangka waktu yang layak dan apabila pemborong tetap mengabaikannya maka apabila pemborong dianggap melakukan wanprestasi seperti yang ditentukan dalam Pasal 1238
KUHPerdata, yang berbunyi si berhutang adalah lalai apabila ia dengan surat perintah atau akta telah dinyatakan lalai dan hal ini si berhutang harus dianggap lalai dengan lewatnya waktu yang ditentukan. Tetapi apabila kemungkinan tersebut tertutup atau tidak ada, maka bank akan tetap melaksanakan pembayaran seperti yang diperjanjikan dalam perjanjian bank garansi.

Kasus No.

PDT/G/2011/PN.PBR Pan United sebagai Penggugat melawan PT Riau Makmur Sentosa sebagai tergugat 1 dan PT. Surya Dumai Agrindo sebagai tergugat 2. Tergugat I adalah perusahaan yang telah mendapatkan Izin Pemanfataan Kayu dari Gubernur Provinsi Riau sesuai dengan Surat Keputusan Gubernur Riau Nomor: Kpts.943/X/2009 tanggal 7 Oktober 2009 tentang Izin Pemanfaatan Kayu (IPK) Di Areal Rencana Land Clearing Perkebunan PT. Riau Makmur Sentosa Kabupaten Bengkalis An. PT. Riau Makmur Sentosa, dengan target produksi sebesar 412.479,90 m3 pada blok tebangan seluas $6.869,80 \mathrm{Ha}$ yang terletak di Desa Sungai Selari, Desa buruk Bakul dan Desa Sejangat Kecamatan Bukit Batu Kabupaten Bengkalis Provinsi Riau;- Penggugat dengan tergugat melakukan perjanjian dengan salah satu syaratnya telah membayar secara penuh 2 (dua) unit Fasilitas Bank Garansi yang didapatkan oleh Tergugat I dari Bank Mandiri Cabang Pekanbaru sebagai syarat untuk mendapatkan Izin Pemanfaatan Kayu. 
Hal ini telah diakui sendiri oleh Tergugat I sesuai dengan Pernyataan yang tertera dalam Akta No. 5 tanggal 10 Juni 2009 yang dibuat oleh atau dihadapan Notaris Benizon, SH, yang pada pokoknya Tergugat I menyatakan bahwa Bank Garansi tanggal 1 Juni 2009 Nomor: MBG7740220894909 senilai US \$ 1,643,875.86 (satu juta enam ratus empat puluh tiga ribu delapan ratus tujuh puluh lima koma delapan puluh enam dollar Amerika Serikat dan Bank Garansi tanggal 1 Juni 2009 Nomor: MBG 7740220895009 senilai Rp. 4.299.450.935,- (empat milyar dua ratus Sembilan puluh Sembilan juta empat ratus lima puluh ribu Sembilan ratus tiga puluh lima rupiah) adalah benar $100 \%$ uang milik Penggugat.

Pada prinsipnya semua perjanjian adalah berdasarkan kesepakatan para pihak yang mengikatkan diri dan wajib dijalankan oleh para pihak yang menyepakati tersebut dalam suatu perjanjian apabila $\mathrm{A}$ telah mengadakan perjanjian dengan $\mathrm{B}$ dan kemudian $\mathrm{B}$ mengadakan perjanjian lagi dengan pihak ketiga, maka jika perjanjian kedua dianggap merugikan debitur, sesuai Pasal 1341 KUH Perdata debitur dapat meminta pembatalan perjanjian tersebut, suatu perjanjian dapat terjadi perbuatan melawan hukum apabila perbuatan tersebut tergolong dalam upaya menghambat pelaksanaan perjanjian. Secara de facto dengan berlangsungnya suatu perjanjian proses peralihan hak telah terjadi, akan tetapi secara de jure masih ada proses yang harus dilalui, jelas bertentangan dengan asas kepatutan.Apabila ada perjanjian kedua yang dibuat dengan pihak lain yang merugikan salah satu pihak pada perjanjian pertama, maka proses pembuatan perjanjian kedua tersebut dapat dikatagorikan sebagai perbuatan melawan hukum. Perbedaan antara wanprestasi dengan perbuatan melawan hukum, wanprestasi atas segala sesuatu yang dikehedaki (kesepakatan) oleh para pihak, agar dipenuhinya isi perjanjian, sedangkan perbuatan melawan hukum adalah atas sesuatu yang tidak dikehendaki (tidak disepakati) para pihak sebelumnya karenanya atas adanya perbuatan dapat dimintakan ganti kerugian, perbuatan melawan hukum tidak hanya melawan hukum yang tertulis, tetapi perbuatan yang melanggar hukum yang tidak tertulis juga dianggap sebagai perbuatan melawan hukum, perbuatan-perbuatan yang menghalangi pencapaian tujuan yang telah disepakati, maka perbuatan itu dapat dikatagorikan perbuatan dengan itikad tidak baik atau perbuatan beritikad buruk.Itikad baik disini bermakna para pihak dengan penuh kejujuran berusaha mewujudkan apa yang disepakati, kalau ada tindakantindakan yang menghalangi maksud yang telah disepakati maka itu bisa dikatakan perbuatan yang beritikad tidak baik atau itikad buruk. Pasal 1365 KUH Perdata akibat adanya perbuatan melawan hukum, lahir kewajiban bagi pihak yang melakukan perbuatan melawan hukum untuk memberikan ganti rugi atas kerugian yang timbul. 
Bahwa wanprestasi adalah kelalaian dalam melaksanakan apa yang telah diperjanjikan baik sebagian atau keseluruhan (memberikan sesuatu, berbuat, dan tidak berbuat) dalam perjanjian bersyarat, apabila syaratsyarat yang ditentukan dalam perjanjian itu tidak terpenuhi, maka perjanjian tersebut dianggapnya tidak pernah ada ini merupakan masalah yang timbul pada bank garansi sebagai salah satu syarat sebuah perjanjian.

Perjanjian pengikatan jual beli antara Tergugat I dan II dimaksud telah memenuhi persyaratan Pasal 1320 KUH.Perdata, oleh karenanya sah menurut hukum berikut segala akibat hukumnya. Karena menurut hukumnya setiap perikatan/ perjanjian yang dibuat oleh kedua pelah pihak yang telah memenuhi syarat formal dan matril perjanjian / kesepakatan apalagi dibuat dihadapan Pejabat Negara (Notaris) adalah sah dan berlaku sebagai undangundang bagi kedua belah pihak sebagaimana menurut ketentuan Pasal 1338 jo 1320 KUH.Perdata, bahwa Pengikatan Jual Beli antara Tergugat I dan II adalah cacat hukum, dalil Penggugat dimaksud adalah sangat tidak beralasan hukum, tidak didukung dengan fakta hukum sebagaimana menurut ketentuan hukumnya, karena untuk dinyatakan suatu akta otentik Perjanjian / Pengikatan cacat hukum haruslah dibuktikan dengan tidak terpenuhinya syarat formil dan syarat matril suatu perjanjian / kesepakatan, sedangkan Penggugat tidak menguraikan dengan jelas syarat formal dan syarat matril dari Perjanjian Pengikatan Jual Beli antara Tergugat I dengan II dimaksud yang tidak terpenuhi syarat formil dan matril sehingga bisa menyebabkan perjanjian dimaksud cacat hukum, oleh karenanya dalil gugatan Penggugat dimaksud haruslah ditolak dan atau setidaktidaknya dinyatakan tidak dapat diterima di dalam Perjanjian.

Atau pada dasarnya didalam garansi bank atau jaminan bank yangnbertindak sebagai penanggung adalah bank. Bank menanggung nasabahnya untuk memenuhi kewajiban karena adanya perikatan pokok yaitu perjanjian tertentu dari pihak ketiga dengan nasabah bank. Tanpa adanya perikatan pokok yang mensyaratkan adanya jaminan bank, penanggungan tidak akan pernah terjadi. Hal ini menunjukkan bahwa perjanjian penanggungan yang dilakukan oleh bank dengan terjamin yang dikenal dengan perjanjian bank garansi bersifat accesoir.

Pengikatan Jual tidak ada klausul yang mengatur adanya larang dan atau tidak ada halangan hukum bagi Penggugat untuk mengambil kayunya, oleh karenanya gugatan Penggugat dimaksud haruslah ditolak dan atau setidak tidaknya dinyatakan tidak dapat diterima. Dan pada dasarnya pemberian bank garansi adalah mutlak jika sudah memenuhi semua persyaratan hal ini supaya dapat mencapai keadilan bagi kedua belah pihak dan untuk menjamin kepastian hukum. Sebaiknya dimasa yang akan datang pihak bank dan 
nasabah dari bank garansi agar penilaian untuk pemberian bank garansi itu di nilai adil sebaiknya ada sebuah lembaga independen tersendiri yang tidak terikat dengan kedua belah untuk mengaudit dan menentukan kelayakan suatu pekerjaan dapat diberikan bank garansi.

Pada dasarnya jika kita memilah dari pada para pihak antara lain bagi pihak Bank, penerbitan bank garansi merupakan salah satu sumber pendapatan bank. Dari penerbitan bank garansi tersebut, pihak bank memperoleh pendapatan dari provisi, biaya administrasi, serta bunga yang dikenakan. Selain itu, bank juga dapat mengopersikan dana jaminan bank garansi (deposit) yang diserahkan oleh nasabah di bidang perkreditan. Bagi pihak terjamin, bank garansi berfungsi sebagai sarana untuk mendapatkan jaminan kepercayaan bahwa ia akan melaksanakan prestasi sesuai dengan yang telah diperjanjikan. Hal ini berarti bank menunjang nasabah agar bisnis atau kegiatan usahanya berjalan dengan baik dan lancar.

Bagi pihak penerima jaminan, bank garansi berfungsi sebagai suatu jaminan untuk terlaksananya suatu prestasi yang telah diperjanjikan. Bank garansi merupakan jaminan penanggungan atas resiko yang akan timbul apabila debitur melakukan wanprestasi.Dari sisi lain, masyarakat juga dapat memetik manfaat dari transaksi bank garansi, yaitu peningkatan arus barang dan lalu lintas pembayaran, kelancaran pembangunan, serta peningkatan kesejahteraan masyarakat. Dengan adanya bank garansi, maka transaksi jual-beli barang dapat terjadi diantara pihak-pihak yang belum saling percaya, arus pemasukan barang dari luar negeri atau daerah lain menjadi semakin lancar, dan pelaksanaan pembangunan proyekproyek juga semakin lancar.

Kasus Nomor 214/Pdt.G/2016/PN Pbr PT Mawatindo Road Contruction merupakan penggugat dan Kementerian Riset, Teknologi dan Pendidikan Tinggi cq Universitas Riau selaku tergugat. Pada tanggal 11 Agustus 2015 antara Penggugat dengan Tergugat telah menandatagani Surat Perjanjian untuk melaksanakan Paket Pekerjaan Konstruksi Pembangunan Konstruksi Gedung B Rumah Sakit Pendidikan UR Nomor: 526/UN 19/PPK/2015 dan Adendum Kontrak Nomor 1091/UN19/PPK/2015 tanggal 10 Desember 2015. Pada tanggal 4 Januari 2016 Tergugat menyatakan Penggugat telah melakukan wanprestasi dan Memutus kontrak Nomor: 526/UN 19/PPK/2015 tanggal 11 Agustus 2015 dan Adendum Kontrak Nomor 1091/UN19/PPK/2015 tanggal 10 Desember 2015 melalui surat Tergugat Nomor: 118/UN 19/KU/2016, Perihal: Pernyataan Wanpresatasi dan Putus Kontrak. pada tanggal 18 Desember 2015, Penggugat mengajukan permohonan penambahan waktu penyelesaian pekerjaan kepada Tergugat melalui surat Nomor 22/MRC-MEP-KSO/XII/15 selama 50 (lima) puluh hari kalender setelah 
berakhirnya kontrak sesuai dengan Perpres Nomor 4 tahun 2015. Adapun alasan Penggugat untuk penambahan waktu penyelesaian pekerjaan adalah sehubungan dengan adanya potensi kehilangan waktu pelaksanaan selama 73 (tujuh puluh tiga) hari kalender. Pada tanggal 23 Desember 2015 Tergugat mengirimkan surat kepada Penggugat yang pada pokoknya menyampaikan bahwa terhitung mulai tanggal 23 Desember 2015 pekerjaan pembangunan gedung B Rumah sakit pendidikan Universitas Riau yang dilaksanakan Penggugat untuk dihentikan pekerjaannya. Adapun alasan yang dijadikan dasar oleh Tergugat untuk memerintahkan Penggugat menghentikan pekerjaan tersebut adalah:Sampai dengan tanggal 23 Desember 2015, kami belum menerima asli garansi bank dan jaminan pemeliharaan; perhitungan pembayaran pekerjaan terakhir adalah berdasarkan pekerjaan terpasang per tanggal 22 Desember 2015; Mawatindo RCMextron EP.JO menyampaikan tidak dapat menyediakan Bank Garansi untuk pekerjaan yang belum diselesaikan (pekerjaan tanggal 23 sampai dengan 31 Desember 2015). Badan Pengawasan Keuangan dan Pembangunan Perwakilan Provinsi Riau telah memberikan penjelasan pekerjaan Pembangunan Gedung B Rumah Sakit Pendidikan Universitas Riau tahun anggaran 2015 yang ditujukan kepada PPK Belanja Modal/Pengadaan Barang dan Jasa APBN,PNBP BLU dan Kegiatan BOPTN Universitas Riau.
Penjelasan ini disampaikan oleh BPKP Provinsi Riau adalah atas surat dari Tergugat Nomor 1152/UN 19/PPK/2015 tanggal 16 Desember 2015 perihal penjelasan pekerjaan mengenai pekerjaan pembangunan gedung B Rumah Sakit Pendidikan Universitas Riau tahun anggaran 2015 dimana kontrak akan berakhir tanggal 31 Desember 2015 sedangkan menurut Peraturan Dirjen Perbendaharaan Nomor: 24/PB/2015 batas waktu pengajuan SPM-LS ke KPPN adalah tanggal 23 Desember 2015. Oleh karena itu PPK akan menempuh pembayaran menggunakan bank garansi sebagai jaminan sisa pekerjaan yang belum selesai sampai tanggal 31 Desember dengan Penilaian progress sebagai dasar menetapkan besaran nilai bank garansi yang harus disiapkan oleh penyedia apakah berdasarkan nilai fisik terpasang atau berdasarkan item terkontrak dimana didalamnya terdapat item pengadaan beton precast (komponen); Progres yang telah tercapai apabila berdasarkan nilai fisik terpasang sebesar $55 \%$ yang sedangkan pekerjaan pengadaan komponen telah tercapai 90\%.Tergugat menyatakan Penggugat melakukan Wanprestasi dan Memutus Kontrak. Adapun alasan yang dijadikan dasar oleh Tergugat untuk menyatakan Penggugat melakukan Wanprestasi dan memutus kontrak adalah berdasarkan berita acara pemeriksaan pekerjaan (BAPP) Nomor: 05/UR-GRSP/BAPT/XII/2015 tanggal 31 Desember 2015, bobot kemajuan pekerjaan hanya mencapai: $57,86 \%$ (lima puluh tujuh 
komadelapan puluh enam persen).Apabila alasan Tergugat adalah bobot pekerjaan maka seharusnya Tergugat menyetujui permohonan Penggugat untuk penambahan waktu pelaksanaan pekerjaan. Dan apabila setelah diberikan penambahan waktu selama 50 hari kalender namun Penggugat tidak mampu menyelesaikan pekerjaan tersebut, maka Tergugat menyatakan Penggugat wanprestasi dan memutus kontrak sebagaimana diatur dalam ketentuan kontrak tersebut. Melakukan perbuatan wanprestasi dan memutus kontrak adalah Tergugat, oleh karenanya Tergugat berkewajiban untuk membayar kepada Penggugat. Adapun alasan Tergugat untuk menyatakan Penggugat wanprestasi dan memutus kontrak adalah karena bobot kemajuan pekerjaan yang dilakukan oleh Pemohon hanya mencapai 57,86\% (lima puluh tujuh koma delapan puluh enak persen) didasarkan pada Berdasarkan Berita Acara Pemeriksaan Pekerjaan (BAPP) Nomor: 05/URGRSP/ BA-PT/XII/2015 tanggal 31 Desember 2015.Dari alasan-alasan pemutusan kontrak yang diatur dalam kententuan surat perjanjian atau kontrak Paket Pekerjaan Konstruksi Pembangunan Gedung B Rumah Sakit Pendidikan UR Nomor: 526/UN 19/PPK/2015 tanggal 11 Agustus 2015 dan Adendum Kontrak Nomor 1091/UN19/PPK/2015 tanggal 10 Desember 2015 bahwa alasan karena bobot kemajuan pekerjaan yang dilakukan oleh Pemohon hanya mencapai $57,86 \%$ (lima puluh tujuh koma delapan puluh enak persen) tidak dapat dijadikan sebagai alasan untuk menyatakan Penggugat wanprestasi dan Tergugat memutus kontrak.

Pada dasarnya pembuatan perjanjian harus seimbang kedua belah pihak atau dengan kata lain hak dan kewajiban harus tercapai sehingga tidak timbul wanprestasi. Dengan keadilan tercapai berarti kepastian hukum sudah terpenuhi dengan baik. Jika salah satu dari hak atau kewajiban para pihak tidak terpenuhi berarti timbul konflik yang menyebabkan masalah salah satunya wanprestasi dan bank garansi yang tidak dapat menjadi jaminan dari pekerjaan padahal bank garansi itu mutlak untuk membantu apabila ditemukan masalah sebagai bentuk jaminan pencairan. Tapi karena bank garansi ini jumlahnya kecil berdasarkan kebutuhan dari si pemborong dan butuh prosedur yang agak lama akibatnya sering perusahaan tidak mau mengandalkan bank garansi kecuali betul-betul butuh karena kadang-kadang karena jumlah persentasenya kecil maka idak mengandalkan pencairannya di lapangan karena hal tersebut memunculkan masalah seperti wanprestasi.

Upaya Hukum Mengatasi Wanprestasi Dalam Pelaksanaan Bank Garansi Sebagai Suatu Jaminan Proyek Dalam Pembiayaan Proyek Pemerintah di Provinsi Riau.

Jaminan dalam bank garansi dimaksudkan sebagai tindakan dari pihak guarantor atau pihak bank untuk 
menjamin bahwa jika seseorang tidak menunaikan kewajiban, misalnya membayar hutang-hutangnya, maka pihak bank tersebutlah yang akan melaksanakan atau mengambil alih kewajiban tersebut. Sedangkan counter guarantee atau jaminan lawan yang cukup dikenal dalam perjanjian bank garansi. Yang dimaksud dengan counter guarantee atau jaminan lawan yang cukup adalah bahwa kontra jaminan yang dimintakan oleh bank dari pemohon bank garansi mempunyai nilai yang memadai untuk menanggung kerugian yang mungkin dipikul oleh bank apabila pemberian bank garansi pada saatnya harus benar-benar direalisir atau dicairkan.

Penerbitan garansi yang dilakukan oleh bank, pihak bank selalu mensyaratkan adanya jaminan lawan atau counter guaranty yang mana nilainya itu ditentukan oleh kebijakan bank namun biasanya setara dengan nilai jaminan yang tercantum dalam garansi bank. Hal tersebut dimaksudkan untuk membatasi resiko yang terjadi dalam penerbitan garansi bank. Jaminan lawan tersebut tidak harus dalam bentuk uang tunai, melainkan dalam bentuk giro, deposito, surat-surat berharga, atau lainnya yang dianggap aman oleh bank. Sifat jaminan lawan tesebut dapat berupa jaminan materi atau bukan materi, seperti jaminan kredit. Dalam hal jaminan lawan yang berupa materi, perlu diadakan penilaian dan pengikatan jaminan lawan sesuai dengan ketentuan hukum yang berlaku disertai dengan tindakan-tindakan lainnya.
Perjanjian pemberian bank garansi tersebut, tanggal mulai dan berakhirnya (jatuh tempo) suatu bank garansi selalu tercantum dalam warkat, bilyet, ataupun sertifikat bank garansi yang bersangkutan. Dengan demikian, bank garansi berakhir apabila: Dikembalikannya bank garansi asli; Batas tanggal berakhirnya masa klaim bank garansi yang telah dilampaui tanpa adanya klaim dari pihak penerima bank garansi; Adanya pernyataan dari penerima bank garansi tentang pelepasan hak klaim atas bank garansi yang bersangkutan.

Pihak yang dijaminkan oleh pihak bank melakukan wanprestasi, maka akan timbul klaim dari pihak penerima jaminan bank dan berakibat harus dicairkannya bank garansi oleh bank penerbit bank garansi selaku bank penjamin. Dalam kasus ini, harus diperhatikan mengenai klaim pembayaran jaminan bank yang hanya dapat diajukan oleh pihak pemegang warkat jaminan bank apabila tidak melebihi jangka waktu sesuai dengan klausul yang tercantum dalam surat bank garansi (yakni 14 hari atau 30 hari sejak berakhirnya bank garansi). Selain itu juga perlu diperhatikan bahwa penerima bank garansi harus menyerahkan dokumen asli surat jaminan bank kepada bank penerbit bank garansi

Berdasarkan akta subrogasi yang telah dibuat sebelumnya, maka dari itu selanjutnya pihak bank yang menerbitkan bank garansi bersamasama dengan pihak nasabah yang 
dijamin membuat akta perjanjian kredit. Hal ini dilakukan dihadapan notaris sesuai dengan Pasal 1401 ayat 2 BW yang mengharuskan kedua bentuk perjanjian di atas dibuat dengan akta otentik.

Pengajuan klaim yang akan dilakukan oleh pihak penerima bank garansi jaminan (beneficiary atau bouwheer), terdapat beberapa syarat yang harus dipenuhi, yaitu: Pertama, dilakukan oleh beneficiary atau bouwheer atau penerima jaminan secara tertulis dengan melampirkan Certificate of Default yang menyatakan bahwa applicant atau nasabah bank telah wanprestasi sesuai dengan underlying transaction-nya dan asli warkat bank garansi maupun dokumen-dokumen lain yang telah dipersyaratkan dalam bank garansi (jika ada); Kedua, dilakukan pada periode berlakunya bank garansi dan selambat-lambatnya pada batas waktu berakhirnya periode klaim atau claim period. Apabila klaim yang diterima setelah berakhirnya batas waktu terakhir pengajuan klaim atau claim period maka pengajuan itu tidak dapat dilayani; Ketiga, pengajuan klaim atau claim period jumlahnya maksimal sebesar nominal bank garansi.

Bagi pihak bank sebagai penerbit bank garansi dalam melakukan pembayaran atas pengajuan klaim yang telah dilakukan oleh pihak yang menerima jaminan (bouwheer atau beneficiary) kepada pihak bank yang disebabkan pihak terjamin atau applicant telah melakukan wanprestasi, maka dapat ditempuh dengan cara yang pertama bank wajib membayar setiap pengajuan klaim atau claim yang dilakukan oleh pihak penerima jaminan, sepanjang telah memenuhi syarat dan ketentuan klaim yang dinyatakan dalam bank garansi dalam waktu 7 (tujuh) hari kerja.

Kemudian cara yang kedua yang harus dilakukan oleh pihak bank dalam rangka pembayaran klaim yaitu bank wajib untuk meneliti terlebih dahulu ketentuan yang berlaku pada warkat bank garansi yang diajukan klaim oleh beneficiary. Apabila bank garansi tersebut tunduk pada Pasal 1832 BW, maka pihak bank akan membayarkan klaim setelah dilakukan eksekusi atas asset yang menjadi agunan atas transaksi bank garansi. Sedangkan apabila bank garansi tersebut tunduk pada ketentuan Pasal 1832 BW, maka pembayaran klaim kepada beneficiary atau bouwheer harus dilakukan selambat-lambatnya dalam 7 (tujuh) hari kerja setelah diterimanya klaim.

Proses penerbitan bank garansi jaminan tender ini contoh pada Bank Rakyat Indonesia sebagai penanggung yang apabila pihak yang dijamian melanggar janji, maka. Bank Rakyat Indonesia sesuai dengan peraturan perundang- undangan yang berlaku akan bertanggung jawab secara penuh kepada pemilik proyek sesuai dengan klausula- klausula yang tercantum dalam bank garansi tersebut.

Penerbitan bank garansi jaminan tender, PT. Bank Rakyat Indonesia adalah sebagai penanggung yang apabila pihak dijamin melanggar janji, 
maka PT. Bank Rakyat Indonesia sesuai dengan aturan dan peraturan yang berlaku di dalam perundang- undangan yang berlaku, akan bertanggung jawab secara penuh kepada pemilik proyek sesuai dengan klausul-klausul yang tercantum dalam bank garansi yang diterbitkan.

Khusus dalam bank garansi jaminan tender, PT. Bank Rakyat Indonesia sebagai penjamin bertanggung jawab apabila nasabah yang dijamin memenangkan tender tetapi tidak sanggup melanjutkan kerjasama dengan pemilik proyek untuk melaksanakan pekerjaan tersebut. Bentuk pertanggung jawaban dari PT. Bank Rakyat Indonesia adalah membayar ganti kerugian kepada pemilik proyek dengan mencairkan kontra garansi 1- $100 \%$ yang sebelumnya telah diserahkan oleh nasabah terjamin. Maksud dari 1-100\% dari kontra garansi ini apabila suatu pemilik proyek sudah bekerja sama dengan Bank rakyat Indonesia dan tidak pernah masuk daftar hitam BI, maka akan diberi keringanan kepada pemilik proyek tersebut dalam memberikan kontra garansi atau jaminan lawan. Apabila pemilik proyek tidak memiliki hubungan kerjasama dengan Bank Rakyat Indonesia maka haru memberikan $100 \%$ kontra garansi, karna dalam hal ini bank tidak mau menanggung kerugian karena pemilik proyek tersebut. Proses Perubahan/Amendment Bank Garansi harus berdasarkan instruksi dari Counter Bank, Perubahan/Amendment decrease harus atas dasar persetujuan beneficiary.

\section{Kesimpulan}

Pelaksanaan bank garansi sebagai suatu jaminan proyek pada pembiayaan proyek pemerintah di Provinsi Riau. telah sesuai dengan ketentuan-ketentuan yang berlaku, namun pada kenyataannya dalam penerbitan bank garansi masih dinilai lambat oleh pihak penyedia jasa hal ini disebabkan karena adanya prinsip kehati-hatian dari pihak bank yang ditetapkan pada proses pemberian bank garansi sehingga diperlukan adanya pemeriksaan terhadap dokumen-dokumen legalitas dan keuangan perusahaan penyedia jasa dan dapat menimbulkan masalah di kemudian hari jika terjadi wanprestasi sehingga masih ada kasus-kasus yang berkaitan dengan bank garansi.

Tanggungjawab para pihak dalam pelaksanaan bank garansi sebagai suatu jaminan proyek dalam pembiayaan proyek pemerintah di Provinsi Riau jika terjadi wanprestasi dapat dilihat hubungan hukum dengan bank yang bersangkutan atau pemohon merupakan nasabah dari Bank yang bersangkutan. Dan semua pihak harus bertanggungjawab jika timbul perbuatan melawan hukum dan wanprestasi dalam pembiayaan proyek yang ada. Hak Bank (Penjamin) adalah hak untuk berubah status menjadi kredit. Bank juga berhak melakukan pemeriksaan dan pengawasan terhadap pemohon Bank Garansi. Kewajiban Bank adalah menerbitkan bank garansi dan membayar klaim kepada pihak yang 
menerima jaminan jika terjamin wanprestasi. Hak kontraktor (terjamin) mempergunakan Bank Garansi untuk mengikuti pelelangan atau pelaksanaan proyek. Kewajiban PT (Persero) Asuransi Kredit Indonesia adalah memberikan kontra garansi.

Upaya hukum mengatasi wanprestasi dalam pelaksanaan bank garansi sebagai suatu jaminan proyek dalam pembiayaan proyek pemerintah di Provinsi Riau adalah apabila ada klaim dari pihak penerima jaminan bank dan berakibat harus dicairkannya bank garansi oleh bank penerbit bank garansi selaku bank penjamin. Dan hanya dapat diajukan oleh pihak pemegang warkat jaminan bank apabila tidak melebihi jangka waktu sesuai dengan klausul yang tercantum dalam surat bank garansi (yakni 14 hari atau 30 hari sejak berakhirnya bank garansi). Selain itu harus menyerahkan dokumen asli surat jaminan bank kepada bank penerbit bank garansi. Apabila pihak penerbit bank garansi atau guarantor terpaksa harus membayar ganti rugi atau klaim yang diajukan oleh pemegang jaminan bank atau bouwheer harus dibuat terlebih dahulu akta subrogasi.

\section{Daftar Pustaka}

Achmad Anwari, 1980, Garansi Bank Menjamin Berhasilnya Usaha Anda, Jakarta: Balai Aksara.

Bambang Sunggono, 2003.Metodologi Penelitian Hukum, Jakarta: Raja Grafindo Persada.
H.R. Daeng Naja, 2005. Hukum Kredit dan Bank Garansi, Bandung: Cetakan Ke-1, PT. Citra Aditya Bakti.

Handari Nawawi dalam Soejono, 2003Metode Penelitian Hukum, Jakarta: Rhineka Cipta.

Ignatius Ridwan Widyadharma,1995. Hukum Perbankan, Semarang: cet 1 , Ananta.

Lia Laurensia, 2007, Pelaksanaan Pemberian Bank Garansi di PT. Bank Ekonomi Raharja Cabang Semarang, Semarang: PPS Universitas Diponegoro.

M. Djumhana,1996,Hukum Perbankan di Indonesia, Bandung: Citra Aditya Bakti.

Thomas Suyatno,2003,M. M., Djuhaepah $\mathrm{T}$. MaralaKelembagaan

Perbankan, Jakarta: PT. Gramedia Pustaka Utama.

Widjanarto,1995 Hukum dan

Ketentuan Perbankan Di

Indonesia, Jakarta: Cet 1 , PT Intermasa.

Surat Edaran Bank Indonesia Tentang Pemberian Garansi Oleh Bank, SEBI No. 23/7/UKU/1991 tanggal 18 Maret 1991.

Asser Rutten,"Penafsiran Kontrak Menurut Kitab Undang-Undang Hukum Perdata dan Maknanya Bagi Para Pihak yang Bersangkutan," Vol. 20, No. 2. Jurnal Hukum Ius Quia Iustum. 